\title{
SATELLITE MONITORING SYSTEMS FOR SHIPPING AND OFFSHORE OIL AND GAS INDUSTRY IN THE BALTIC SEA
}

\author{
A.G. Kostianoy ${ }^{1,2,4}$, E.V. Bulycheva ${ }^{3}$, A.V.Semenov $^{4}$, A. Krainyukov $^{5}$ \\ ${ }^{I}$ P.P. Shirshov Institute of Oceanology, Russian Academy of Sciences, \\ Moscow, Russia, Nakhimovsky Pr. 36 \\ E-mail: kostianoy@gmail.com \\ ${ }^{2}$ Immanuel Kant Baltic Federal University, \\ Kaliningrad, Russia, Aleksandra Nevskogo Str. 14, Build. 2 \\ E-mail: kostianoy@gmail.com \\ ${ }^{3}$ Atlantic Branch of P.P. Shirshov Institute of Oceanology, Russian Academy of Sciences, \\ Kaliningrad, Russia, Prospekt Mira 1 \\ E-mail: bulycheva.lena@gmail.com \\ ${ }^{4}$ S.Yu. Witte Moscow University, \\ Moscow, Russia, Second Kozhukhovsky Pr. 12, Build. 1 \\ E-mail: semen7777@gmail.com \\ ${ }^{5}$ Transport and Telecommunications Institute \\ Lomonosova iela 1, Riga, LV-1019, Latvia \\ Phone:+371 67100634. Fax: +37167100660 \\ E-mail: Krainukovs.A@tsi.lv
}

\begin{abstract}
Shipping activities, oil production and transport in the sea, oil handled in harbors, construction and exploitation of offshore oil and gas pipelines have a number of negative impacts on the marine environment and coastal zone of the seas. In 2004-2014 we elaborated several operational satellite monitoring systems for oil and gas companies in Russia and performed integrated satellite monitoring of the ecological state of coastal waters in the Baltic, Black, Caspian, and Kara seas, which included observation of oil pollution, suspended matter, and algae bloom at a fully operational mode. These monitoring systems differ from the existing ones by the analysis of a wide spectrum of satellite, meteorological and oceanographic data, as well as by a numerical modeling of oil spill transformation and transport in real weather conditions. Our experience in the Baltic Sea includes: (1) integrated satellite monitoring of oil production at the LUKOIL-KMN Ltd. D-6 oil rig in the Southeastern Baltic Sea (Kravtsovskoe oil field) in 2004-2014; (2) integrated satellite monitoring of the "Nord Stream" underwater gas pipeline construction and exploitation in the Gulf of Finland (2010-2013); (3) numerical modeling of risks of oil pollution caused by shipping along the main maritime shipping routes in the Gulf of Finland, the Baltic Proper, and in the Southeastern Baltic Sea; (4) numerical modeling of risks of oil pollution caused by oil production at D-6 oil rig and oil transportation on shore via the connecting underwater oil pipeline.
\end{abstract}

Keywords: the Baltic Sea, oil pollution, satellite monitoring, shipping, oil and gas pipelines, environmental risk assessment, numerical modeling

\section{Introduction}

Oil and oily residue discharges from ships, offshore platforms, and oil terminals represent a significant threat to marine ecosystems. These discharges may occur during normal activities or may be accidental or illegal. Oil spills cause the contamination of seawater, bottom sediments, shores, and beaches, which may persist for several months and even years (Kostianoy and Lavrova, 2014c). The world average release of petroleum from all sources to the World Ocean is estimated at 1.3 million tons per year, however, the range is wide from 0.47 million tons to a possible 8.4 million tons per year (Global Marine..., 2015). According to different national and international reports, the main categories of sources contribute to the total oil input as follows: discharges from ships and land-based sources $-24-47 \%$, natural seeps $-7-46 \%$, and offshore extraction - only 2-3\% (Global Marine..., 2015). 
Public interest in the problem of oil pollution arises mainly during dramatic tanker and oil platform catastrophes such as "Amoco Cadiz" (France, 1978), "Ixtoc I" (Gulf of Mexico, 1979-1980), "Exxon Valdez" (Alaska, 1989), "The Sea Empress" (Wales, 1996), "Erica” (France, 1999), "Prestige” (Spain, 2002), "Fu Shan Hai" (the Baltic Sea, 2003), and "Deepwater Horizon" (Gulf of Mexico, 2010). According to the International Tanker Owners Pollution Federation (ITOPF, 2015), over the period of 1974-2014, spillages resulting from allisions/collisions, groundings, hull and equipment failures and fires/explosions amounted to $47 \%$ of total leakages during tanker loading/unloading and bunkering operations. In the last 45 years (1970-2014) we have observed a significant decrease in the number of the medium (7-700 tons) and large (>700 tons) sized oil spills - from 54.3 and 24.5 in average in 1970's to 5.2 and 1.8 in 2010's. The decade total quantity of oil spilt has also decreased from 3.2 million tons in 1970 's to 208,000 tons in 2000's, and to 26,000 tons in 2010-2014 (ITOPF, 2015).

However, tanker and oil platform catastrophes are only a few among many causes of oil pollution. Oil and oil product spillages at sea take place all the time, and it would be a delusion to consider tanker accidents the main environmental danger. Discharge of wastewater containing oil products is another important source, by pollutant volume comparable to offshore oil extraction and damaged underwater pipelines. The greatest, but hardest-to-estimate oil inputs come from domestic and industrial discharges, direct or via rivers, from the atmosphere and from the natural hydrocarbon seeps. The long-term effects of this chronic pollution are arguably more harmful to the coastal environment than a single, large-scale accident (Lavrova et al., 2011; Kostianoy and Lavrova, 2014a,b).

The Baltic Sea is one of the busiest waterways in the World Ocean. It has about 40 ports and oil terminals. The last one was officially open on 23 March 2012 in Ust-Luga (Russia) in the Gulf of Finland. According to the HELCOM AIS, there are about 2,000 ships in the Baltic Sea every day, and each month about 3,500-5,000 ships ply the waters of the Baltic Sea. It is estimated that $15 \%$ of the world's trade and $11 \%$ of the world's oil transportation pass through the Baltic Sea waters. These values may increase by 64\% between 2003 and 2020. For example, the oil transportation increased by 133\% between 1997 and 2008 and is now over 250 million tons per year (Pålsson, 2012).

In the last 15 years a number of new oil terminals have been built in the Baltic Sea area, resulting in increased transport of oil by tankers and, consequently, an increased risk of accidents (Kostianoy and Lavrova, 2014a). Thus, shipping activities, including oil transport and oil handled in harbours, may have a major negative impact on the marine environment, marine protected areas, and coastal zone in the Baltic Sea (Kostianoy et al., 2008, 2014a; Kostianoy and Lavrova, 2014a).

As concerns oil exploitation at sea and on the coast, offshore operations have been taking place for some years in Polish waters (two jack-up rigs); Germany operated two platforms very close to the coast; in March 2004 Russia started the oil production at continental shelf in the waters between the Kaliningrad area (Russian Federation) and Lithuania, as well as there are Latvian plans to drill for oil in the waters between Latvia and Lithuania (Global Marine..., 2015). So far as the Baltic Sea ecosystem undergoes growing human-induced impacts, especially associated with an increasing oil transport and production, one of the main tasks in the ecological monitoring of the Baltic Sea is an operational satellite and aerial detection of oil spillages, determination of their characteristics, establishment of the pollution sources and forecast of probable trajectories of the oil spill transport.

Despite the fact that the Baltic Sea has only $0.1 \%$ of the World Ocean surface, at the beginning of 2000 s, the oil pollution volume was estimated from about 1,000 to 35,000-60,000 tons a year (Patin, 2008; Kostianoy, 2013; Kostianoy and Lavrova, 2014b).

Oil pollution monitoring in the Mediterranean, North and Baltic seas is normally carried out by aircrafts or ships (Kostianoy, 2008). This is expensive and is constrained by the limited availability of these resources. Aerial surveys over large areas of the seas to check for the presence of oil are generally limited to the daylight hours in good weather conditions. Satellite radar imagery can help greatly identifying probable spills over very large areas (up to $400 \mathrm{x} 400 \mathrm{~km}^{2}$ ) and then guiding aerial or ship surveys for precise observation of specific locations. The Synthetic Aperture Radar (SAR) instrument, which can collect data almost independently of weather and daylight conditions, is an excellent tool to monitor and detect oil on water surface. This instrument offers the most effective means of monitoring oil pollution: oil slicks appear as dark patches on SAR images because of the damping effect of the oil on the backscattered signals from the radar instrument. This type of instrument was/is currently on board the European Space Agency's ENVISAT (till 8 April 2012) and ERS-2 (till 5 September 2011) satellites, the Canadian Space Agency's RADARSAT-1 (till 29 March 2013) and RADARSAT-2 satellites, the German Earth observation satellite TerraSAR-X, Italian COSMO-SkyMed satellites, and others.

The "Nord Stream" offshore gas pipeline construction was the biggest offshore project performed in 2010-2012 in the Baltic Sea. This is a transport system designed for natural gas export from Russia to Germany and then to the European Union via the Baltic Sea. The pipeline offshore route $1220 \mathrm{~km}$ long transects the Exclusive Economic Zones (EEZ) of five states - Russia, Finland, Sweden, Denmark and Germany, as well as waters of the territorial seas of Russia, Germany and Denmark. Its construction and 
exploitation requested satellite monitoring of all four types of potential contaminants and impacts: oil pollution, suspended matter, algal bloom, and thermal effects which are well tracked from satellites (Grishin and Kostianoy, 2012a,b, 2013; Kostianoy et al., 2014c).

Since 2003, in cooperation among P.P. Shirshov Institute of Oceanology (Moscow) and its Atlantic Branch in Kaliningrad, Russian Space Research Institute (Moscow), Geophysical Center (Moscow), and Marine Hydrophysical Institute (Sevastopol) we elaborated several operational satellite monitoring systems for oil and gas companies in Russia and performed complex satellite monitoring of the ecological state of coastal waters in the Baltic, Black, Caspian, and Kara seas in a fully operational mode (24/24 and 7/7) (Kostianoy et al., 2009; Lavrova et al., 2011). Our experience includes:

(1) Elaboration of the integrated satellite monitoring system (2004) and monitoring of the LUKOIL-KMN Ltd. D-6 oil rig in the Southeastern Baltic Sea in 2004-2014;

(2) Elaboration of the integrated satellite monitoring system (2007) and monitoring (2010) of the underwater gas pipeline "Dzhubga-Lazarevskoe-Sochi" construction in the Eastern Black Sea;

(3) Elaboration of the integrated satellite monitoring system (2006) and monitoring (2010-2013) of the "Nord Stream" underwater gas pipeline construction and exploitation in the Gulf of Finland, the Baltic Sea;

(4) Elaboration of the integrated satellite monitoring system for the underwater gas pipeline "Bovanenkovo-Ukhta" construction in the Baydaratskaya Guba, the Kara Sea (2007);

(5) Elaboration of the integrated satellite monitoring system for the Caspian Sea (2008);

(6) Elaboration of the structure and principles of the integrated satellite monitoring system organization for all coastal seas of Russia (2009-2010);

(7) Numerical modeling of risks of oil pollution caused by shipping along the main maritime shipping routes in the Gulf of Finland, the Baltic Proper, and in the Southeastern Baltic Sea;

(8) Numerical modeling of risks of oil pollution caused by oil production at D-6 oil rig and oil transportation on shore via the connecting underwater oil pipeline.

The above mentioned satellite monitoring systems differ from the existing ones by the analysis of a wide spectrum of satellite, meteorological and oceanographic data, as well as by a numerical modeling of oil spill transformation and transport in real weather conditions. The known accidents with tankers in the sea or that on the BP oil platform "Deepwater Horizon" on 20 April 2010 in the Gulf of Mexico showed that absence of such a permanent integrated satellite monitoring system makes low effective all efforts related to cleaning operations at sea and on the shore during the first days after the accident (Lavrova and Kostianoy, 2010).

In this paper we will focus on a brief review of our experience in the Baltic Sea.

\section{Satellite monitoring of oil production at the «LUKOIL-Kaliningradmorneft» D-6 oil rig in the Southeastern Baltic Sea}

Since 1993 there has been no regular aerial surveillance of the oil spills in the Russian sector of the Southeastern Baltic Sea and in the Gulf of Finland. In June 2003 LUKOIL-KMN Ltd. initiated a pilot project, aimed to the integrated monitoring of the Southeastern Baltic Sea, in connection with a beginning of oil production at oil rig D-6 at continental shelf of Russia in March 2004 (cut-in (1) in Fig. 1). From 2004 to present (2015), in the framework of the industrial environmental monitoring of the oil field "Kravtsovskoe" (D-6) and a number of Russian and international research projects satellite monitoring of oil pollution of the sea surface in the Southeastern Baltic Sea is carried out (Kostianoy et al., 2006, 2014b; Bulycheva and Kostianoy, 2011, 2014; Lavrova et al., 2011, 2014; Bulycheva et al., 2014). The main directions of this research are: (i) daily radar control of the appearance and drift of oil slicks on the sea surface by the near real time data from different satellites; (ii) detection and identification of possible sources of oil pollution through the AIS system (Automatic Identification System for identifying and locating of vessels); (iii) forecast of the direction and speed of the oil spill drift with the Seatrack Web numerical model of the Swedish Meteorological and Hydrological Institute; (iv) collection and analysis of the auxiliary satellite, meteorological and oceanographic information; (v) systematization and storage of the information. As a result, integrated information on oil pollution of the sea, spatial distribution of the sea surface temperature, suspended matter, chlorophyll concentration, algal bloom, currents and meteorological parameters have been received on a regular base.

Since 2004, to detect oil pollution on the sea surface we have been using radar (SAR/ASAR) images from ENVISAT satellite of the European Space Agency (ESA) (before its failure in April 2012), RADARSAT-1 of the Canadian Space Agency (CSA) (before its failure in March 2013) and RADARSAT-2 of the MacDonald, Dettwiler and Associates Ltd. (MDA, Canada). Acquisition and delivery of these radar images are carried out by the Norwegian satellite operator Kongsberg Satellite Services (KSAT) in Tromsø. 
During the analysis of 1844 radar images of the sea surface in the Southeastern Baltic Sea received from 12 June 2004 till 31 December 2014 (cut-in (2) in Fig. 1) we identified in total 1193 oil spills. Fig. 1 shows a cumulative map of all oil spills (with a real shape and size) detected in the monitoring area for the period 2004-2014. We have to note that the density of the satellite image coverage is not uniform over the shown area of the Baltic Sea, because the monitoring was focused on the D-6 oil rig in coastal waters of Russia. This partially reflects on the number of oil spills detected in different parts of the investigated area with their higher density eastward of $18^{\circ} \mathrm{E}$ and southward of $57^{\circ} \mathrm{N}$ (Fig. 1).

The oil spills are mainly localized and concentrated along the main shipping routes in the Baltic Sea: southwestward, southward and eastward of Gotland Island (four lines); lines leading to the ports of Riga, Ventspils, Liepaja, Klaipeda, Baltiysk/Kaliningrad, Gdansk and Gdynia (see Fig. 1). In the vicinity of the D-6 oil rig for 11-year period, not a single case of oil pollution has been fixed. There is a relatively clean sea surface along the coast of the Curonian Spit. This is obviously due to the low activity of shipping, as well as due to currents typical for this area, which transport surface contamination mainly to the north-west, north, north-east (Bulycheva et al, 2014; Bulycheva and Kostianoy, 2014).

In the Russian sector of the Southeastern Baltic Sea the most polluted area is waters to the west of the Sambia Peninsula and on the approach to the Kaliningrad Canal (near Baltiysk), where several shipping routes from the north and west converge (see Fig. 1) (Bulycheva et al, 2014; Bulycheva and Kostianoy, 2014). Anchorage area at the entrance to the Kaliningrad Canal, in different years and by different statistics based on satellite observations is regarded as the most polluted area of the Southeastern Baltic Sea, and, perhaps, the whole Baltic Sea (Kostianoy et al., 2006, 2014b; Bulycheva and Kostianoy, 2011, 2014; Lavrova et al., 2011, 2014; Bulycheva et al., 2014). The accumulation of oil spills northward of the Sambia Peninsula near the port of Pionersky, outside of the main shipping routes (see Fig. 1), could be explained by discharges from small fishing vessels not equipped with AIS (Bulycheva et al, 2014).

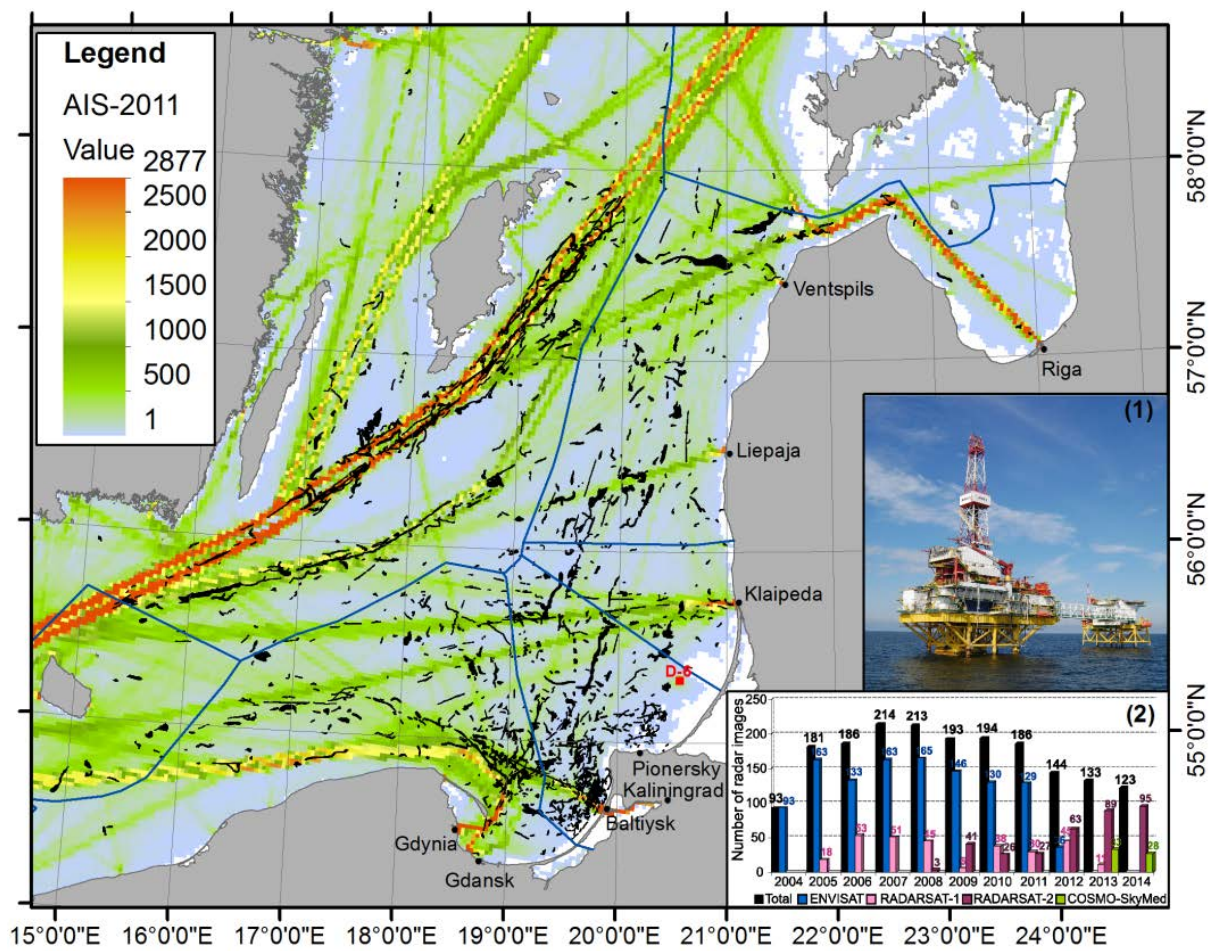

Figure 1. A cumulative map of all oil spills detected in this part of the Baltic Sea for the period 2004-2014 on the color background of AIS density for 2011. Cut-in (1) - The LUKOIL-KMN Ltd. oil rig D-6 in the Southeastern Baltic Sea; cut-in (2) The number of SAR/ASAR images received and analyzed in 2004-2014

Thus, the main reason for oil pollution in the Baltic Sea is shipping, which includes oil and chemical tankers, cargo, container, military ships, ferries, fishery boats, and even passenger ships.

From 2006 to 2011 there was a steady decline in the total number of oil spills (from 212 to 44), detected on radar images, as well as in the total area of oil pollution (from about 833 to $147 \mathrm{~km}^{2}$ ) (Fig. 2). These figures correspond to the lower level of the real oil pollution of the sea surface because of the limitations of the method used (satellite radiolocation) and the time gaps between satellite passes, which sometimes reach two days. Nevertheless, there is a clear decreasing trend in the interannual variability of 
oil pollution in this part of the Baltic Sea. It should be noted that, according to the HELCOM data for the 1988-2011, a similar trend is observed for the whole area of the Baltic Sea (Kostianoy and Lavrova, 2014). In 2012, there was a jump in the number of detected oil spills and, as a consequence, in the total area of oil pollution (see Fig. 2). In 2013, when a small amount of oil slicks was observed, a large total area of oil pollution was fixed due to three huge oil spills detected on 13 September 2013 in Russian EEZ $\left(72 \mathrm{~km}^{2}\right)$, 20 September 2013 in Swedish EEZ $\left(92 \mathrm{~km}^{2}\right)$, and 23 May 2013 in Latvian EEZ $\left(34 \mathrm{~km}^{2}\right)$. All these oil spills were leakages from the moving ships. In 2014, the level of oil pollution returns to the level of 2011 in terms of total spills number and pollution area. Figs. 3-6 show several examples of oil pollution detected on radar imagery in 2005-2014.

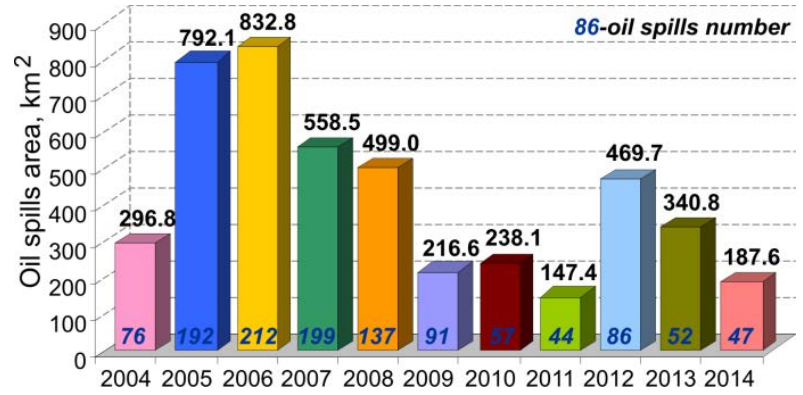

Figure 2. Interannual variability (2004-2014) of the total number of oil spills and polluted area in the part of the Baltic Sea shown in Fig. 1

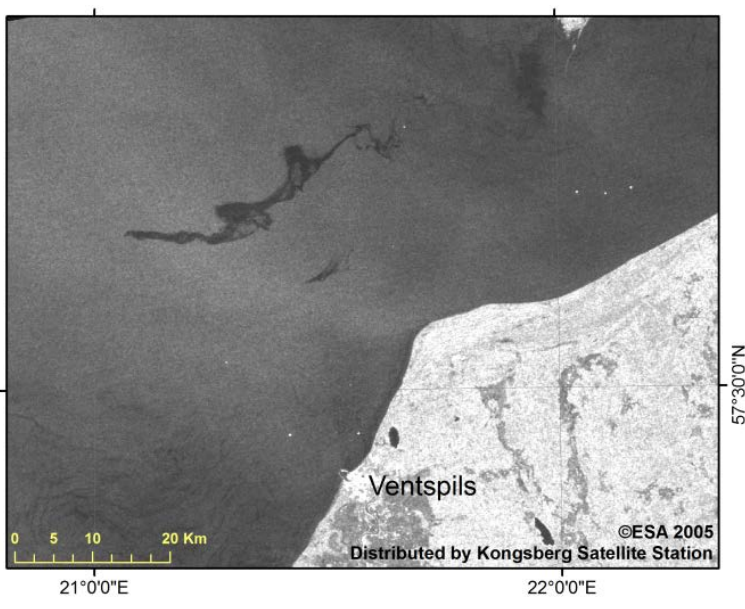

Figure 3. ASAR Envisat, 28.05.2005, 20:19 UTC.

Oil pollution northward of Ventspils. Total length - $42 \mathrm{~km}$, total area $-79.2 \mathrm{~km}^{2}$

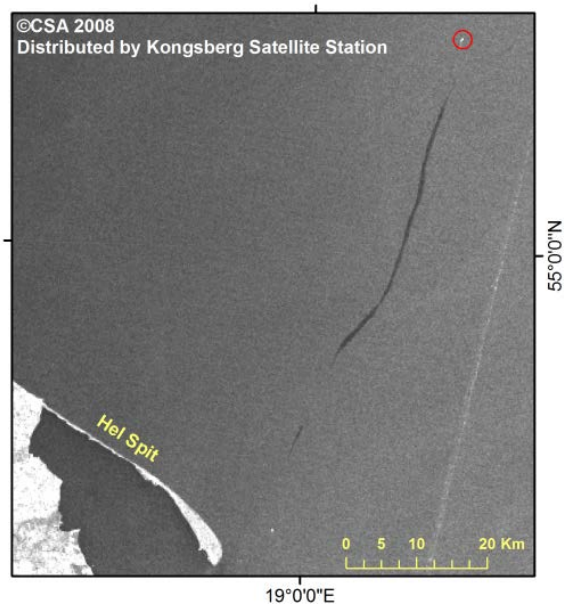

Figure 5. SAR RADARSAT-1, 24.07.2008, 05:04 UTC.

Oil discharge from a moving ship (in red circle). Total length - $46 \mathrm{~km}$ total area $-23.3 \mathrm{~km}^{2}$

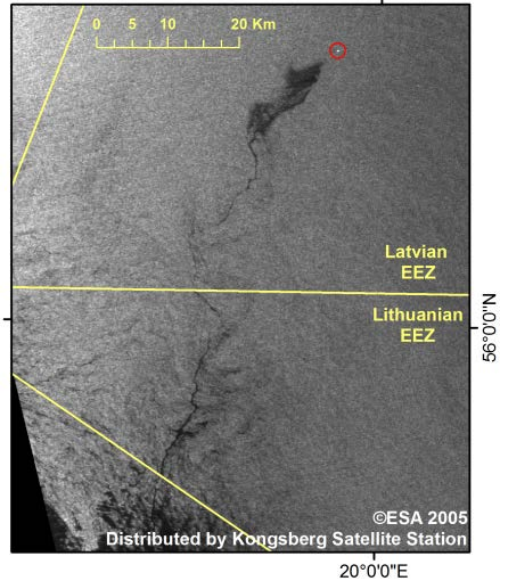

Figure 4. ASAR Envisat, 04.09.2005, 20:05 UTC Fresh oil spill from a moving vessel (in red circle). Length $-72 \mathrm{~km}$

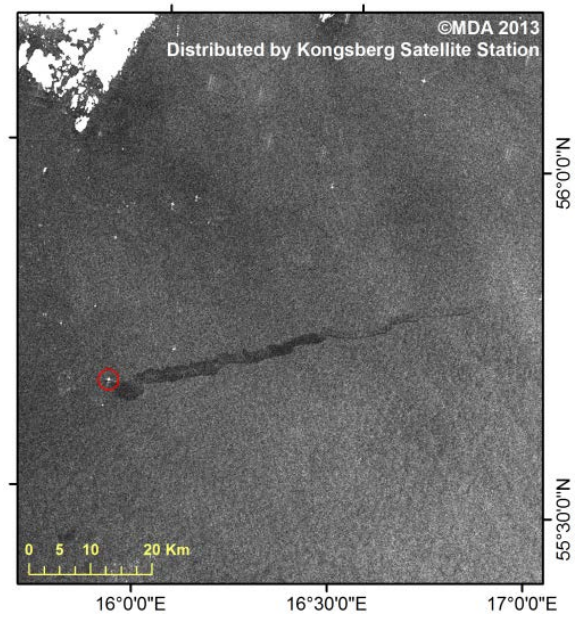

Figure 6. RADARSAT-2, 20.09.2013, 05:05 UTC. Fresh oil spill from a moving vessel (in red circle). Length $-60 \mathrm{~km}$. Total area $92 \mathrm{~km}^{2}$ 


\section{Numerical modeling of oil spill drift and risks of oil pollution caused by oil production at D-6 oil rig}

We used the interactive numerical model Seatrack Web of Swedish Meteorological and Hydrological Institute (SMHI) for a forecast of the drift of: (1) all large oil spills detected by SAR/ASAR imagery in the Baltic Sea (Figs. 7, 8) and (2) virtual (simulated) oil spills from the D-6 oil rig (Figs. 9- 12). The latter was done daily for operational correction of the action plan for elimination of a potential accident at the D-6 oil rig and Environmental Risk Assessment (oil pollution of the sea and the Curonian Spit) (Kostianoy et al., 2008, 2014a; Kostianoy and Bulycheva, 2014).

This version of a numerical model on the Internet platform has been developed at SMHI in close co-operation with Danish authorities. The system uses two different operational weather models ECMWF and HIRLAM (HIgh Resolution Limited Area Model, $22 \mathrm{~km}$ grid) and circulation model HIROMB (HIgh Resolution Operational Model for the Baltic sea, 24 layers, driven by the two weather models respectively), which calculates the current field at $1 \mathrm{~nm}$ grid with $15 \mathrm{~min}$ time step. The model allows to forecast the oil drift for five days ahead or to make a hindcast (backward calculation) for 30 days in the whole Baltic Sea. When calculating the oil drift, wind and current forecasts are taken from the operational models. An oil spreading calculation is added to the currents, as well as oil evaporation, emulsification, sinking, stranding and dispersion. This powerful system today is in operational use in Sweden, Denmark, Finland, Poland, Estonia, Latvia, Lithuania and Russia (Kostianoy et al., 2008, 2014a; Kostianoy and Bulycheva, 2014).

Fig. 7 shows the results of numerical modeling of the drift of an oil spill detected northward of Ventspils on 28 May 2005 (see Fig. 5) during 48 hours from 28 to 30 May 2005. Fortunately, during these two days there was no strong wind and currents that could drift this huge oil spill (42 km long and $79.2 \mathrm{~km}^{2}$ large) to the coasts of Latvia or Estonia (Saaremaa Island). The next satellite image acquired 12 hours later has proved this forecast and showed that the weathered oil spill remained almost at the same place.

Another interesting case study was done on 9 April 2013 when an oil spill was detected by RADARSAT-2 on 16:15 UTC at a distance of about $10 \mathrm{~km}$ from the D-6 oil rig (Fig. 8). The shape of the slick and specific contrast at its boundaries showed that it drifted from north-east to south-west till the time of satellite image acquisition. Between the D-6 oil rig and oil spill two ships were located. Backward model calculation of the spill drift has showed that the detected oil spill was located at a distance of $3 \mathrm{~km}$ from the oil rig on 01:00 UTC on 9 April where it arrived from north-west (see Fig. 8). Thus, we can exclude the D-6 oil rig from a list of potential polluters, and on the other hand point out on the right ship as a source of oil pollution, because the spill trajectory has passed exactly via its location (see Fig. 8).

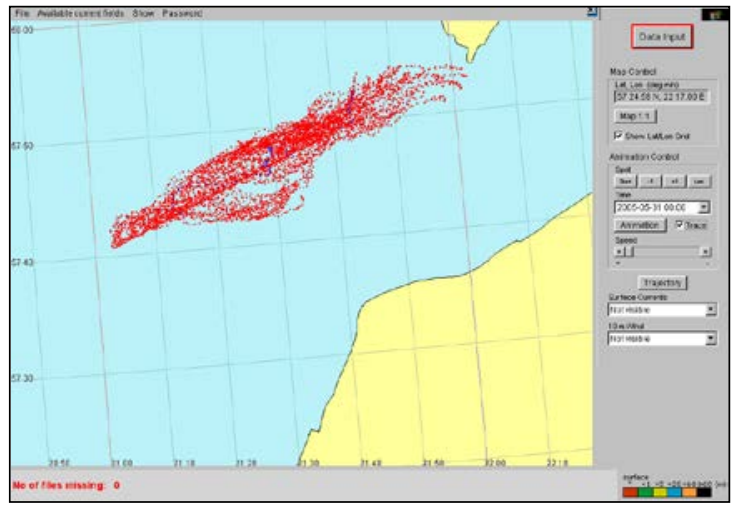

Figure 7. Numerical modeling of the drift (28-30 May 2005) of an oil spill detected northward of Ventspils on 28 May 2005 (see Fig. 5)

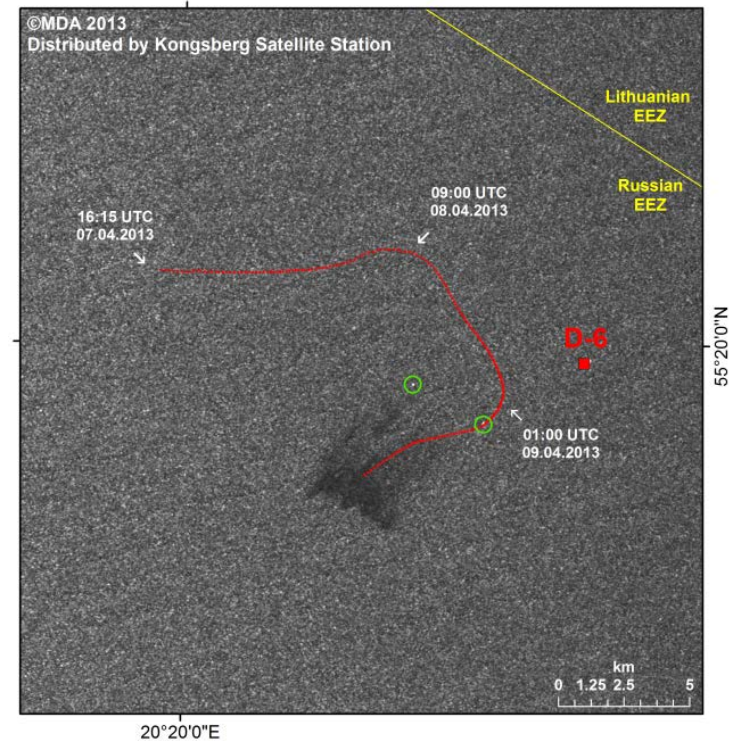

Figure 8. Backward trajectory (red line) of a drift of an oil spill detected by RADARSAT-2 on 9 April 2013 (16:15 UTC). Green circles show two ships located close to the polluted area. Red dot is the D-6 oil rig 
In 2004-2005 we daily modeled the drift of an oil spill of $10 \mathrm{~m}^{3}$ released from the D-6 oil rig during 48 h (Kostianoy et al., 2006, 2008, 2014a). Fig. 9 shows just one example of such a drift on 25 October 2005. This shallow area of the Southeastern Baltic Sea is characterized by strong variability of wind and currents speed and direction which result in a strong variability of daily individual trajectories of oil spill drift. This justifies the use of operation metocean data in the numerical modeling, as it is performed in the Seatrack Web model, instead of averaged climatic meteorological and hydrodynamic characteristics normally used in the Environmental Risk Assessment. Statistics, based on daily forecast of the oil spills drift from the D-6 oil rig in July-December 2004, shows potential probability (\%) of the appearance of an oil spill in any point of the area during $48 \mathrm{~h}$ after an accidental release of oil (Fig. 10).

The same type of numerical modeling was done from 1 January 2013 to 31 December 2014 (Kostianoy and Bulycheva, 2014). Cumulative drift trajectories of the modeled oil spills released at D-6 oil rig in January 2013 are shown in Fig. 11. The obtained results demonstrate that at the prevailing eastward winds (for example, in October and November 2013) the modeled oil spills will never reach the coast of the Curonian Spit, because they will be advected by the alongshore currents to the north-east direction. The cumulative forecast of an oil spill drift based on daily modeling during January-December 2013 showed that during the first $48 \mathrm{~h}$ after a potential accident at the D-6 oil rig the oil spill will never reach the coastline. Potential probability (\%) of an oil spill observation on the water area around the D-6 oil rig during $48 \mathrm{~h}$ after an accident in 2013 is shown in Fig. 12 (Kostianoy and Bulycheva, 2014).

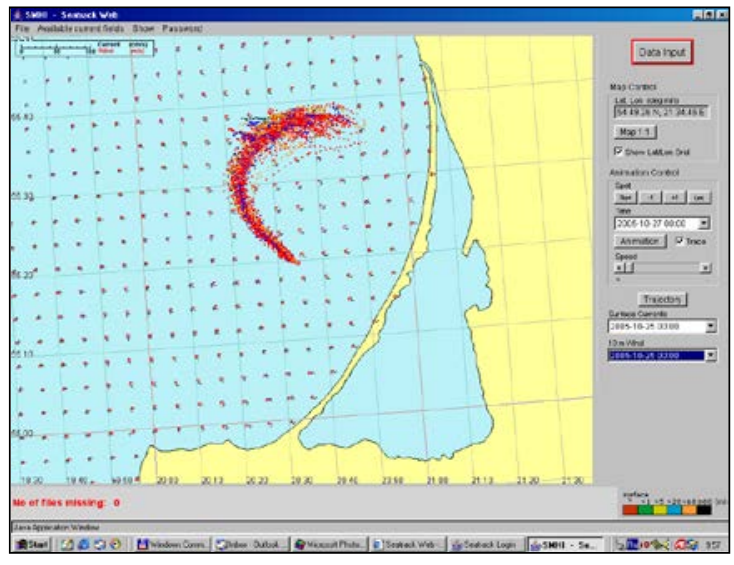

Figure 9. An example of daily forecast of the virtual (simulated) oil spill drift from the D-6 oil rig on 25 October 2005

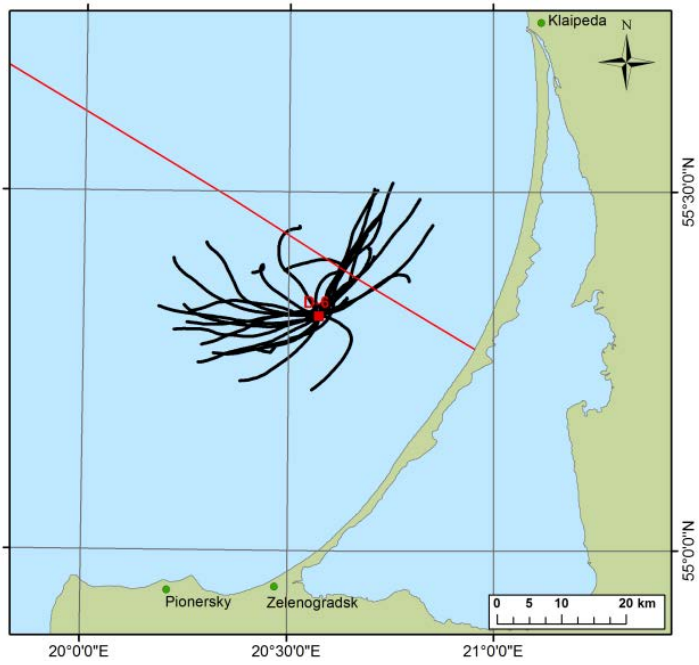

Figure 11. Cumulative drift trajectories of the center of potential oil spills released at D-6 oil rig in January 2013

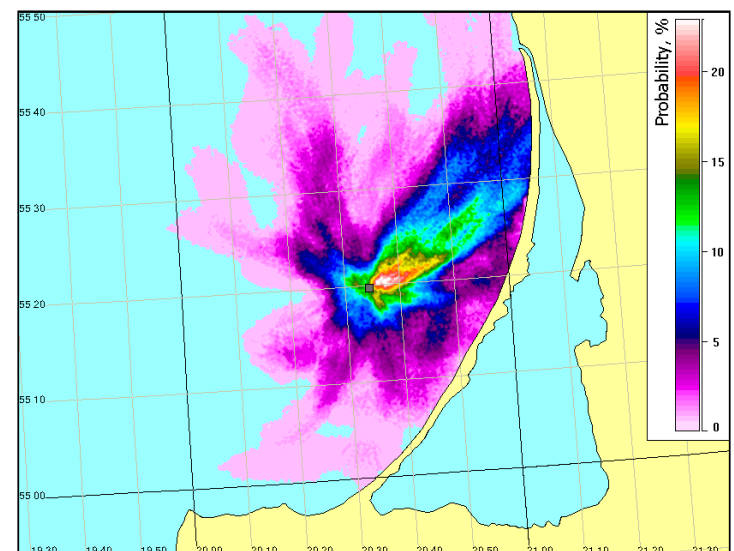

Figure 10. Probability of observation of potential oil pollution from D-6 oil rig during the first 48 hours after an accidental release of $10 \mathrm{~m}^{3}$ of oil

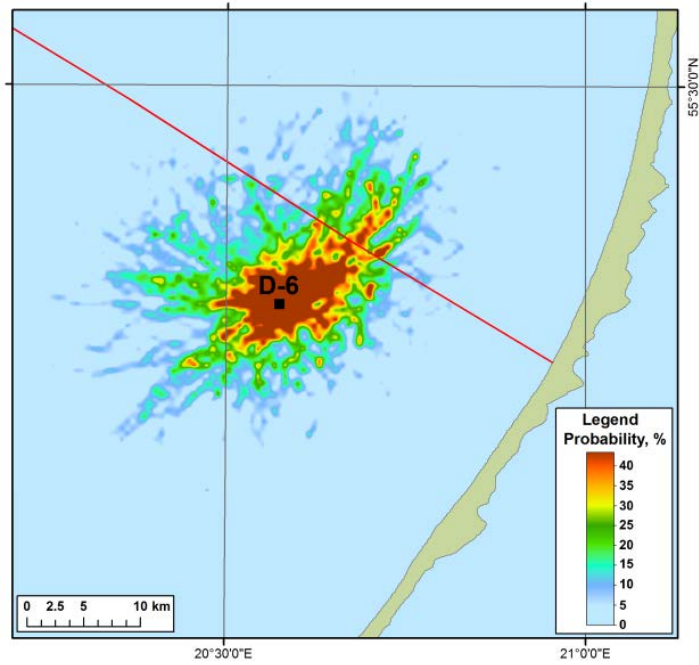

Figure 12. Probability of an oil pollution (\%) during $48 \mathrm{~h}$ after a potential accident at D-6 oil rig for January-December 2013 


\section{Satellite monitoring of the "Nord Stream" underwater gas pipeline construction in the Gulf of Finland}

The "Nord Stream" is a more than 1200-km long offshore gas pipeline that link Russia to Europe via the Baltic Sea from Vyborg in Russia to Greifswald in Germany. The construction in the sea has started in April 2010. The first line of the Nord Stream was completed in June 2011 and put into operation on 8 November 2011. The second, parallel pipeline has started in May 2011 and it was put into operation in October 2012. The construction process of the pipeline may cause, in particular, the following impact on the marine environment: (i) oil pollution due to the operation of ships, pipe lay ships, dredge ships and mechanisms in the sea; (ii) increase of suspended matter concentration due to dumping of sand and gravel, and dredging operations; (iii) provoking of local algal bloom events in summertime due to vertical mixing resulted from dumping and dredging works (Grishin, Kostianoy, 2012a,b, 2013; Kostianoy et al., 2014c). In many parts of the Baltic Sea the "Nord Stream" pipeline coincides with the main shipping route crossing the sea from the Gulf of Finland to the southwestern part of the Baltic Sea. Along this ship route we have already been yearly observing the maximum of oil spills discharged from ships well before the "Nord Stream" construction (Kostianoy et al., 2006). Besides, we observe very large areas of water with a high concentration of total suspended matter (TSM) and areas of very intense algal bloom. Both are observed yearly and have natural reasons. Thus, there are two very important and interrelated tasks: (i) to monitor in the operational regime the ecological state of the sea at the site of the pipeline construction, and (ii) to discriminate between natural effects and anthropogenic impacts, related to the construction itself. Moreover, oil spills must be distinguished between "own" pollution and "alien" pollution originated from the passing ships.

Since May 2010 till December 2013 in the framework of the contract with the "Nord Stream" Company we performed daily satellite monitoring of TSM distribution on the sea surface in the Gulf of Finland. The main factors for increasing the concentration of TSM during the construction of offshore gas pipelines are preparation of the seabed for the laying the pipeline by constructing pillars of gravel at the bottom grooves to avoid sagging of the tube (pre-lay rock dumping) and follow-up with gravel filling (post-lay rock dumping) in order to achieve a stability of the pipe at the bottom during gas transport, as well as pipe-laying of the tube itself. Dredging in Portovaya Bay for burial of the pipeline in the bottom can also lead to an increase in water turbidity. Analysis of daily satellite imagery during four years of monitoring showed that plumes of turbid waters occasionally appeared along the coasts of Finland, Estonia, southern coast of Russia and in the Gulf of Vyborg (Fig. 13). They were produced by a windwave mixing of coastal waters and a runoff of small rivers after the rains. The area of water with high concentration of TSM (due to natural causes) in some places ranged from 100 to $1,000 \mathrm{~km}^{2}$ (Fig. 13). Most clearly the formation of suspended matter fields related to the construction of the pipeline was seen only in Portovaya Bay during the construction of dams and dredging (Fig. 14).

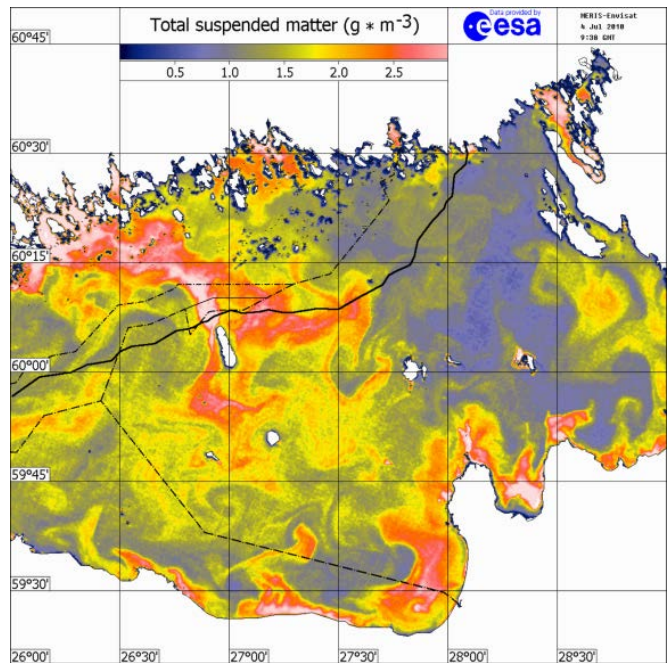

Figure 13. Spatial distribution of TSM in the surface layer of the eastern part of the Gulf of Finland on 4 July 2010 (09:38 GMT) basing on the MERIS Envisat data (C2010, ESA) (black line - Nord Stream gas pipeline route, dashed lines are marine borders between countries, white areas are coasts and islands)

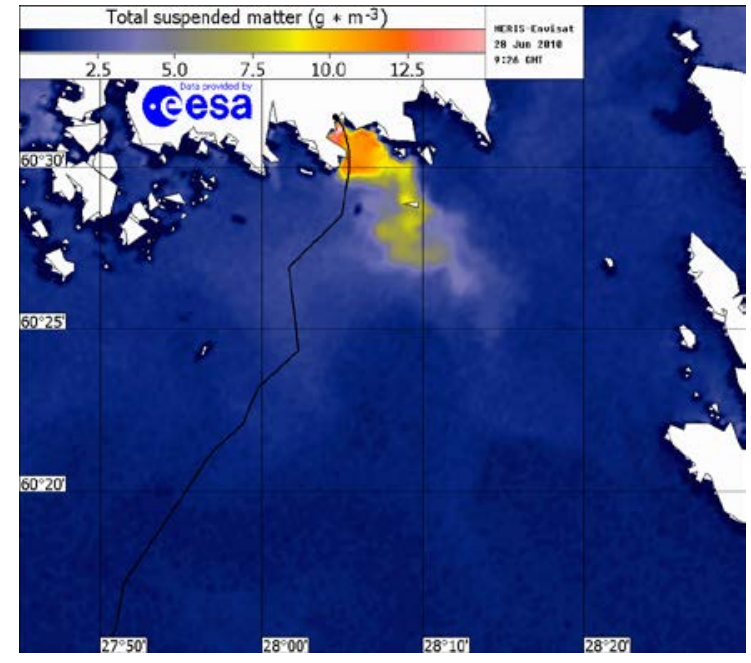

Figure 14. Spatial distribution of TSM in Portovaya Bay and surrounding waters of the northeastern part of the Gulf of Finland on 28 June 2010 (09:26 GMT) basing on the MERIS ENVISAT data (C2010, ESA). Turbid area is of $8 \mathrm{~km}^{2}$ 


\section{Numerical modeling of risks of oil pollution caused by shipping along the main maritime shipping routes in the Baltic Sea}

In the framework of several projects related to organization of the integrated satellite monitoring of the D-6 oil platform in the Southeastern Baltic Sea and a construction of the "Nord Stream" gas pipeline in the whole Baltic Sea we elaborated a new, very effective technology for the quantitative Environmental Risk Assessment, based on the Seatrack Web model (Kostianoy et al., 2008, 2014a; Kostianoy and Bulycheva, 2014). For every kilometer of the coastline, the Baltic Sea Protected Area, Important Bird Area, as well as for any part of the sea surface it allows to calculate in the probability to be polluted by oil, resulted from operations in ports, oil terminals, oil platforms, oil pipelines, and shipping activities in the Baltic Sea. This technology was applied to different points of the shipping route crossing the Baltic Sea from St.-Petersburg to Germany (Kostianoy et al., 2008, 2014a).

From 19 September to 18 November 2014 we carried out numerical simulation of a drift of potential oil pollution along the shipping route in the Gulf of Finland. The total length of the selected line from the St.-Petersburg Dam to the exit from the Gulf of Finland is about $400 \mathrm{~km}$. In the model, along the route, $40 \mathrm{~m}^{3}$ of lubricating oil was daily evenly poured to the sea and the forecast of the oil pollution drift was calculated for the next $48 \mathrm{~h}$. Sixty one experiments revealed five areas of probable contamination: (i) Hogland Island; (ii) other islands in the waters of the Russia; (iii) small islands off the coast of Finland west of Helsinki; (iv) the northern and (v) southern coast of Russia in the extreme eastern part of the Gulf of Finland. No cases of contamination of islands and the coast of Estonia were recorded. Fig. 15 shows a typical situation when oil pollution drifts from the shipping line to the north, which is observed in most cases because of the prevailing winds in the Gulf of Finland which are directed to the northeast.

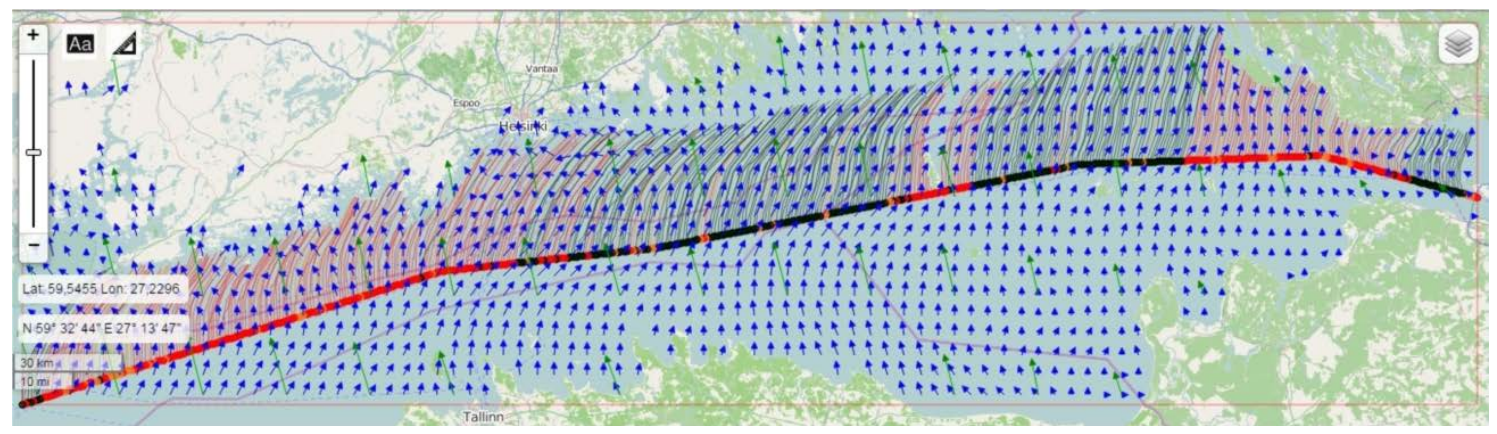

Figure 15. Oil pollution drift in the Gulf of Finland on 24 October 2014

\section{Conclusions}

In 2004-2014 we elaborated and performed an integrated approach to operational monitoring of the Southeastern Baltic Sea in connection with the beginning of oil production on the D-6 oil rig at continental shelf of Russia in March 2004. In 2010-2013 we used the same system for a monitoring of the "Nord Stream" gas pipeline construction and exploitation in the Gulf of Finland. As a part of this system we also elaborated a new, very effective technology for the quantitative Environmental Risk Assessment, based on the Seatrack Web model. This technology has been applied to different installations of oil and gas industry, as well as to shipping activities in the Baltic Sea.

\section{Acknowledgements}

The research has been supported by the Russian Science Foundation under the project N 14-50-00095. Satellite radar data were provided by LUKOIL-KMN, Ltd.

\section{References}

1. Bulycheva, E.V. and Kostianoy, A.G. (2011) Results of the satellite monitoring of oil pollution in the Southeastern Baltic Sea in 2006-2009. Modern problems of remote sensing of the Earth from space, V8, N 2, 74-83 (in Russian).

2. Bulycheva, E.V. and Kostianoy, A.G. (2014) Results of satellite monitoring of the sea surface oil pollution in the Southeastern Baltic Sea in 2004-2013. Modern problems of remote sensing of the Earth from space, V11, N 4, 111-126 (in Russian). 
3. Bulycheva, E., Kuzmenko, I. and Sivkov, V. (2014) Annual sea surface oil pollution of the southeastern part of the Baltic Sea by satellite data for 2006-2013. Baltica, V27, Special Issue, 9-14.

4. Global Marine Oil Pollution Information Gateway (2015). Online at http://www.oils.gpa.unep.org/ (as of 15 February 2015).

5. Grishin, N. and Kostianoy, A. (2012a) Satellite monitoring of suspended matter pollution resulted from the Nord Stream gas pipeline construction in Russian waters of the Baltic Sea in 2010-2011. International Water Technology Journal, V2, N1, 80-89.

6. Grishin, N.N. and Kostianoy, A.G. (2012b) On satellite monitoring of suspended matter transport during the construction of an offshore gas pipeline Nord Stream in Russian waters of the Baltic Sea in 2010. Modern problems of remote sensing of the Earth from space, V9, N 1, 167-175 (in Russian).

7. Grishin, N.N. and Kostianoy, A.G. (2013) The use of satellite monitoring of suspended matter transport for the assessment of transboundary environmental impact of construction the Russian section of the offshore gas pipeline Nord Stream. Modern problems of remote sensing of the Earth from space, V10, N 1, 303-319 (in Russian).

8. ITOPF (2015) Oil tanker spill statistics 2014. ITOPF, London, UK, 12 pp. http://www.itopf.com/knowledge-resources/data-statistics/statistics/ (as of 15 February 2015).

9. Kostianoy, A.G. (2008) Satellite monitoring of oil pollution in the European Coastal Seas, OCEANIS, V34, N 1/2, 111-126.

10. Kostianoy, A.G. (2013) Oil pollution: Baltic Sea. In: Encyclopedia of Environmental Management, (Ed.) S.E. Jorgensen, Taylor \& Francis, New York, 2013, V.III, 1851-1866.

11. Kostianoy, A., Ambjorn, C., and Soloviev, D. (2008) Seatrack Web: a numerical tool to protect the Baltic Sea marine protected areas. - Proc., US/EU Baltic 2008 International Symposium "Ocean Observations, Ecosystem-Based Management and Forecasting”, May 27-29, 2008, Tallinn, Estonia.

12. Kostianoy, A.G., Ambjörn, C., and Solovyov, D.M. (2014a) Seatrack Web - a Numerical Tool for Environmental Risk Assessment in the Baltic Sea. In: Oil pollution in the Baltic Sea. (Eds.) A.G. Kostianoy and O.Yu. Lavrova, Springer-Verlag, Berlin, Heidelberg, New York, V27, 185-220.

13. Kostianoy, A.G. and Bulycheva, E.V. (2014) Numerical simulation of risks of oil pollution in the Southeastern Baltic Sea and in the Gulf of Finland. Modern problems of remote sensing of the Earth from space, V11, N 4, 56-75 (in Russian).

14. Kostianoy, A.G. and Lavrova, O.Yu. (Eds.) (2014a) Oil pollution in the Baltic Sea. Springer-Verlag, Berlin, Heidelberg, New York. V27. 268 pp.

15. Kostianoy, A.G. and Lavrova, O.Yu. (2014b) Introduction. In: Oil pollution in the Baltic Sea. (Eds.) A.G. Kostianoy and O.Yu. Lavrova, Springer-Verlag, Berlin, Heidelberg, New York, V27, 1-13.

16. Kostianoy, A.G. and Lavrova, O.Yu. (2014c) Conclusions. In: Oil pollution in the Baltic Sea. (Eds.) A.G. Kostianoy and O.Yu. Lavrova, Springer-Verlag, Berlin, Heidelberg, New York, V27, 249-263.

17. Kostianoy, A.G., Lavrova, O.Yu. and Mityagina, M.I. (2009) Integrated satellite monitoring of oil pollution in the Russian seas. In: "Problems of Ecological Monitoring and Modelling of Ecosystems”, Yu.A. Izrael (Ed.), V 22, 235-266 (in Russian).

18. Kostianoy, A.G., Lavrova, O.Yu., Mityagina, M.I., Solovyov, D.M. and Lebedev, S.A. (2014b). Satellite monitoring of oil pollution in the Southeastern Baltic Sea. - In: Oil Pollution in the Baltic Sea, Springer-Verlag, Heidelberg, V27, pp.125-154.

19. Kostianoy, A.G., Lavrova, O.Yu., Mityagina, M.I., and Solovyov, D.M. (2014c) Satellite monitoring of the Nord Stream gas pipeline construction in the Gulf of Finland. In: Oil Pollution in the Baltic Sea, (Eds.) A.G. Kostianoy and O.Yu. Lavrova, Springer-Verlag, Heidelberg, V27, P. 221-248.

20. Kostianoy, A.G., Litovchenko, K.Ts., Lavrova, O.Yu., Mityagina, M.I., Bocharova, T.Yu., Lebedev, S.A., Stanichny, S.V., Soloviev, D.M., Sirota, A.M., and Pichuzhkina, O.E. (2006). Operational satellite monitoring of oil spill pollution in the southeastern Baltic Sea: 18 months experience. Environmental Research, Engineering and Management. 4(38), 70-77.

21. Lavrova, O.Yu. and Kostianoy, A.G. (2010) A catastrophic oil spill in the Gulf of Mexico in AprilMay 2010. Russian Journal for Remote Sensing, N6, 1-5 (in Russian).

22. Lavrova, O.Yu, Kostianoy, A.G., Lebedev, S.A., Mityagina, M.I., Ginzburg, A.I., Sheremet, N.A. (2011) Complex satellite monitoring of the Russian seas. Moscow: IKI RAN, 470 pp. (in Russian).

23. Lavrova, O.Yu., Mityagina, M.I., Kostianoy, A.G., and Semenov, A.V. (2014) Oil pollution in the Southeastern Baltic Sea in 2009-2011. Transport and Telecommunication, V15, N4, 322-331.

24. Pålsson, J. (2012) Oil spill preparedness in the Baltic Sea countries. Baltic Master II Project. World Maritime University. $42 \mathrm{pp}$.

25. Patin, S.A. (2008) Oil spills and their impact on the marine environment and living resources. Moscow, VNIRO Publishing, 508 pp (in Russian). 